\title{
Book review: Dobeson A, 2019: Revaluing coastal fisheries: how small boats navigate new markets and technology, Palgrave Macmillan, Switzerland
}

\author{
John Kurien ${ }^{1}$ ii \\ Received: 8 October 2020 / Accepted: 19 January 2021 / Published online: 28 January 2021 \\ (C) The Author(s), under exclusive licence to Springer-Verlag GmbH, DE part of Springer Nature 2021
}

How nature interfaces with markets, influences technology and in turn conditions the way humans organize their lives is not a common theme dealt with by economists or sociologists. Perhaps, this is due to the fact that most studies of market, technology and institutions deal with sectors of the economy and society where the determining influence of nature per se is not of much consequence. Nature may be present, but is very much in the backdrop.

Marine fisheries is one sector where nature is central to the dramatic interplay of humans, technology, markets and institutions and therefore cannot be wished away so easily. This is not to make a case for a deterministic role for nature. However, the reality is that the vicissitudes of the fluid ocean and its fugitive resources, as well as the inability to bring them under the total control of humans or technology, make for keeping nature as a central actor in any worthwhile academic rendering of marine fisheries.

Alexander Dobeson's treatise on Iceland's small boat fishery is a fine relational ethnographic account of the multiple human and non-human actors and sites in the Icelandic fishery while it was undergoing a tumultuous change - after the unprecedented financial crash of the Icelandic economy in 2008. Dobeson's book vividly describes the time between 2012 and 2014 when small-scale fishers could either move out of the fishery or find new ways of coping, staying in and staying afloat. The sea, its vagaries and moods, what it gives and takes, are mainstreamed in the narrative.

Dobeson's book is a 'must read' for the now increasing number of academicians and researchers who are showing enormous interests in small-scale fishers and other rural producers in order to understand how they are negotiating their

John Kurien

john.kurien@apu.edu.in

$1 \quad$ Azim Premji University, Bengaluru, India economic, social and cultural transitions in the rapidly changing global economy. The book is rich in theoretical references and frames which adds to its scholarly standing in the field of economic sociology.

The narrative of the book is largely seen through the eyes of a fisher named Bjartur (meaning 'the bright'). He lives in the remote Westfjords of Iceland. He gave up the lucrative job of being a first mate on a large trawler and chose to become an independent fisher and his own master in his home community. Today, he manages his own smábátar (small boat) trying to realize his childhood dream of making a hard but honest living from it for himself and his family.

As the background to Bjartar's decision, we have the controversial, much researched and discussed individual transferable quota (ITQ) system in marine fisheries which Iceland gradually began to implement from the early 1990s. This was part of a larger global neo-liberal agenda of privatization and commodification of fishery resources world over in the wake of increased global demand for cheap protein. Initially the small boat (below 15-m length) coastal fishery was insulated from the ITQ system. However, with growing 'technology stuffing', small boats were able to fish round the year and beyond the coastal waters as well, and by 2004 the full-fledged ITQ system was also introduced into the coastal fishery. Quotas were allocated according to historical catch records of the small boats in the community. However, as quotas could be bought and sold across geographic locations, the concept of a self-reliant and largely self-contained village community, dependent on a few small boats, could be put in jeopardy.

Dobeson's book is about how Bjartar, and others like him, in the new and emerging context of capitalist neoliberal inclusion, cease to be just skilled coastal fishers. Their world goes far beyond the 'locally bound fishing community to a broader globalised web of markets, property rights, international financial markets, scientific discourses and technological developments'. However, they are firm in their resolve to remain small-scale, independent and community-oriented. 
Dobeson explains that this process did not lead to a 'disembedding' where social relations are lifted out from the local context of interactions in the community. The communities also did not totally 'lose their integrative function in favour of the calculative logic of large-scale industrial capital and rationalist production regimes'.

The author's remit is not to defend an organic fishing community against the designs of capital's ingress into their midst with new markets, rights and technology. He is not promoting the small-scale fishery against the large. But he does try to explain the metamorphosis of Bjartar, and small fishers like him, in the Icelandic context, by providing an elaborate account 'of the social dynamics, practices and tensions that characterise and challenge the boundaries of today's rural economies in the wake of a new culture of liberal capitalism'. It is this effort which makes the story in the book go beyond fisheries and Iceland. It voyages into the realms of worldwide transformation of natural resources and ecosystem communities in this neo-liberal era.

The book has nine chapters, the first being the Introduction. The second chapter deals with the manner in which marketbased reforms and the introduction of property rights, specifically the individual transferable quotas, transform the fishery. The third chapter investigates the historical, social and cultural role of coastal fisheries in Iceland and how the entry and acceptance of new market reforms and private rights transform rural production networks. The fourth chapter gives a first-hand account of the relation between fishers and the way they coordinate their work at sea. The fifth chapter, titled 'Enframing the Sea', investigates the rising role of digital technology which help fishers to 'see' the fish before they catch it and how these changes influence their conception of the whole natural environment in which they operate. The sixth chapter discusses the unique fact of fish not playing to the dictates of the market and how fishers cope with this and the technological complexity of modern fishing. The interesting feature of fish being more valuable in their true fresh state, without any processing whatsoever, and the challenges and great opportunities this provides for small boats undertaking single-day fishing to provide top quality fresh fish to buyers, is the subject of the seventh chapter. The eighth chapter titled 'The Fishery Panopticon' is a novel exposition of how the digital technologies and automatic identification systems (AIS) help fishers to keep an eye on the fish, as well as their fellow fishers, buyers and global markets. Interestingly, it also allows buyers to keep an eye on the fishers to know where, what and how they fish. Hence, the imagery of the panopticon! The final chapter raises the issue about the relative success of Bjartar in defending his freedom and independence in coastal Iceland. More generally, the chapter raises two Gandhian questions: how can small and labourintensive industries navigate liberal capitalism and how big can small become in the current neo-liberal age.
The dominant narrative in the book is indeed about the transformation of the small-scale fishery of Iceland. The acceptance of ITQs and the need to compete with the large-scale fishery lead to the inevitable technological transition with regard to boat designs and propulsion, fish gear operations, fishing finding, navigation, and communication gadgets. This is then integrally linked to the overall digitalisation of market transactions. The investments required for making these technological transitions have been substantial and also inevitably led to a much higher degree of indebtedness in the form of financial entanglements with fish processing companies and the formal banking system. The inevitable consequence of both the above resulted in the small-scale fishery also becoming increasingly profit-oriented, which resulted in concentration of ownership rights within this sector. What followed was a change in the legal size of small-scale boats (from 15 to $30 \mathrm{t}$ ) which brought them more in line with the size of large vessels.

Data from the FAO show that despite this deliberate largescaling of the fishery, the total number of fishing vessels in Iceland between 2010 and 2017 exhibited only a small reduction from 1625 to 1602, and the marine fish harvest during the same period shows but a marginal increase from 1.06 million tonnes to $1.16 \mathrm{t}$ (FAO 2019).

This data, when juxtaposed with the narrative in the book, raises the question as to who has really benefitted from the substantial increase in investments in the Icelandic fishery and the change to a more pervasive individualist and profitoriented culture-even in the once communitarian smallscale fishery. Was it the technology companies, the banks, the buyers or the processors?

Dobeson provides the answer to this question by informing us that Bjartar is both hero and victim and agent and object of this socio-technical change and cultural transformation. Bjartar initially gets 'disentangled' from his strong community ties and 're-entangled' in a new web of money-mediated relations with creditors to guarantee financial liquidity to stay afloat. Dobeson concludes very well that 'it is a translation of socio-technical arrangements, institutions, identities and network ties that has been unfolded in an oscillating process of disentanglement and re-entanglement of economic expectations that transforms the culture of the coastal fisheries from symbol and means of rural independence to a new liberal culture of market-based entrepreneurship and profit-making'.

Though Dobeson does not state it so bluntly, this is indeed just an exulted form of post-modern enslavement.

Markets develop in a marine fishery, much earlier than in other primary sectors. This is due to the simple reason that every fishing trip is a lottery. If a fisher harvests more than his consumption requirement, then he is confronted with a "surplus' which must be exchanged if it is not to be wasted. As a result, even with a very low development of productive forces (as in artisanal small-scale fishing) a 'market' emerges. The fact that fish continues to be the most internationally traded 
primary commodity ( $35 \%$ of global production is traded) is importantly also the aggregation of these 'micro-surpluses'.

However, the Covid-19 pandemic has in several countries highlighted the sensibility and viability of decentralized, small-scale, self-employed, localized fishing for fresh fish, giving priority to hinterland domestic markets. Realizing this, small-scale fishers world-over, and their supporters, are grappling with the issue of how to re-envision the small-scale fishery into a convivial post-Covid market economy.

Dobeson inadvertently makes a prognosis for this vexing issue in his poignant concluding statements of the book: 'The question therefore should not be whether one is for or against the 'free market', but about the boundaries, ownership structures and the regulations that frame and define the cultural form of the coastal fisheries in a market economy. The people of Iceland and of other fishing nations flirting with market-based solutions to resource management may ask themselves the following questions: What are the cultural and social values of coastal fisheries? How shall we define their boundaries? What is their function in contemporary society? Furthermore, should a few quota-owners have the power to accumulate large amounts of fishing quotas and vessels? Or even more critically, should not those who go to sea own the right to fish, as the old Icelandic- Peir fiska sem róa-(Those fish who go to sea) suggests?'. (Dobeson 2019 page 223)
In the interest of getting a much larger non-academic, but practitioner readership for his book, how I wish Dobeson had taken recourse to first providing a full and detailed analytical description of his excellent account of the transition of Iceland's rural small-scale fishery through the story of Bjartar. He could have then interrogated the various theoretical frameworks to show how they speak to or embellish his narrative, highlighting then his own unique contributions to the discourse of economic sociology. But that is perhaps for another occasion and another form.

\section{Compliance with Ethical Standards}

Conflict of Interest The author declares that there is no conflict of interest.

\section{Reference}

Dobeson, A. 2019. Revaluing coastal fisheries: how small boats navigate new markets and technology. London: Palgrave Macmillan.

FAO 2019. FAO yearbook, Fishery and Aquaculture Statistics 2017. Rome

Publisher's note Springer Nature remains neutral with regard to jurisdictional claims in published maps and institutional affiliations. 